Canadian Journal of Family and Youth, 13(2), 2021, pp. 26-43

ISSN 1718-9748@ University of Alberta

http://ejournals,library,ualberta.ca/index/php/cjfy

\title{
Parenting Styles as a Determinant of Career Choice among Undergraduates with Disabilities at the University of Ilorin
}

\author{
Florence Bosede Famolu
}

\begin{abstract}
Several factors have emerged as a major concern in parenting styles as a determinant of career choice among undergraduates with disabilities at the University of Ilorin. This study examined the importance of parenting styles as a determinant of career choice including the concepts of gender, religion, age and level. A descriptive survey designed was adopted. The population consists of undergraduates with disabilities at the University of Ilorin, Kwara State. One research question was raised and four null hypotheses were postulated in the study. Data were collected using a questionnaire tagged "Parenting Styles as a Determinant of Career Choice among Undergraduates with Disability (PSDCCUDQ)". Data analysis was done using t-test and Analysis of Variance (ANOVA). The results obtained revealed that discussing the problem that many encountered during the 'choosing my choice of career' is the most influential parenting style as a determinant of career choice among undergraduates with disabilities at the University of Ilorin. The findings of the study also revealed that there were no significant differences in the perception of respondents on parenting styles as a determinant of career choice based on gender, age, religion but there was a significant difference in the respondents' perception on parenting styles as a determinant of career choice based on level. Based on the findings of this study, it was recommended that professional school counsellors should provide collaborative support and training to parents on career guidance.
\end{abstract}

Keywords: parenting styles, career choice, undergraduates, disability, University of Ilorin

Dr. Florence Bosede Famolu is a Lecturer in the Department of Guidance and Counselling, Faculty of Education, Osun State University, Osogbo, Nigeria. She is a member of the Counselling Association of Nigeria and is a registered member of the Teachers' Registration Council of Nigeria (TRCN). Recent publications include: Famolu F.B. \& Adelekan F.B. (2018): An Evaluation of Leadership Styles and Influence on Employees Performance in Work Organisations: A Study of Banking Industry. Journal of African Sustainable Development. 11 (8), 117-141. Published by Hummingbird Publications and Research International, Centre for Industrial Studies (CIS), S Abubakar Tafawa Balewa University, Bauchi, Bauchi State, Nigeria and Ilesanmi, O.A. Famolu, F. B. Ajibola, K.S, \& Bakare, A.A. (2018): Role of Punishment as a Managerial Strategy in Nigerian Organisations. International Journal of Management Science and Entrepreneurship. 12 (5), 58-72. Published by Department of Accounting and Banking Operations. Al-Azhar University, Cairo Egypt. 


\section{Introduction}

Choosing a career is an extremely important decision that impacts an individual's entire future. Career exploration is defined as the extent to which possible careers are researched and considered. Navin (2019) has suggested that exploring career options before committing to a career increases future career success and satisfaction. Thus, variables that influence career exploration in adolescents should be identified and acknowledged. In our society today, students face a complex and rapidly changing society. It has been reported that regardless of great effort put forth by families, government agencies and non-government agencies, many young people encounter difficulties in the transition from the world of school to that of work (Atchoarena cited in Pilot \& Regis, 2012). Investigating and better understanding the myriad factors that contribute to career choice is a topic of recurring interest in our schools today.

The teenage years are often portrayed as stressful for both parents and teens. Trusty, Watts, and Erdman (2017) demonstrates that teens undergo a number of developmental adjustments including biological, cognitive, emotional and social changes on their way to becoming adults. Parenting effectively during the teen years, as in any developmental period, requires a thorough understanding of these normative developmental changes. Parents can benefit from an understanding that how the parent or their parenting style provides a basis for many healthy developmental outcomes during adolescence. Understanding the different parenting styles and their impact on the parent-teen relationship may help parents and their teens navigate adolescence more smoothly (Fisher \& Griggs, 2014; Trusty, Watts, \& Erdman, 2017; Adegboyega, 2017).

Navin (2019) asserted that parental attachment has been shown to be positively correlated with career exploration. Navin found that parental attachment, defined as the extent to which one feels emotionally close to and supported by one's parents, was positively related to career exploration. Similarly, according to Navin (2019), Lee and Hughey (2011) found out that parental attachment was positively correlated with career maturity, which is defined, as how prepared an adolescent is to make career decisions. Though career maturity may not be synonymous with career exploration, career exploration is a necessary step in the process of gaining career maturity.

Navin (2019) affirmed that parental attachment is important for self-efficacy, defined as how confident an individual is that he/she will be good at his/her future career. Effective career exploration is necessary to facilitate feelings of career self-efficacy. This study also lends support to the idea that parental attachment is important for career exploration. Some researchers have suggested that the reason for the relationship between parental attachment and various aspects of career development is that a secure attachment to one's parents provides a safe place for one to go for emotional support (Navin, 2019).

A parenting style is the overall emotional climate in the home. It is a psychological construct representing standard strategies that parents use in child rearing. Parental investment starts soon after birth. Parenting styles can be said to be the overall approach parents take to guiding, control and socializing their children, the attitudes that parents have about their children and the resulting emotional climate that is created (Spera, 2015). Also, it can be said to be specific practices with which parents influence their children (Gwen, 2010; Adegboyega, Ibitoye, 
Okesina \& Lawal, 2017). Parenting style is affected by both the parent's and the children's temperaments and is largely based on the influence of one's own parents, culture, family type and the relationship between the parents (Alegre, 2008). Many parents create their own style from a combination of factors and these evolve over time as the children develop their personalities and move through life's stages.

Parenting styles are also said to be different manners of parent-child relationship. Parenting can be more enjoyable when positive parent-child relationship is established. The number one behaviour of the parent-child relationship that impacts the individual's development is communication. Good communication that impacts the individual's development is communication good communication is an important parenting skill. Whether one is parenting a toddler or an adolescent, good communication is the key to building self-esteem as well as mutual respect. The absence of high-quality communication can lead to unstable family environment (Baumrind, 2011).

Parental education and occupational status are highly correlated with children's educational choices and attainment. Dustman (2014) found that parental background is strongly related to the choice of secondary school track of the child and this association translates into substantial differential differences in earnings later in life. Education, economic incentives and parental influence are sometimes used as pressure to induce the young adolescents into predetermined careers, regardless of the potentials, actual needs and age of the child (Egbochukwu, 2009; Adegboyega, 2019).

Career development is regarded as a sequence of developmental experience which culminates not only in vocation choice but also in life long career pattern as well. Career education and awareness usually starts from where parents relate the daily life of the child to work skills exhibited. Empirical findings have confirmed to a greater extent, the impact of the family in which a person lives and family goals and objectives on his/her career choice.

This problem is traceable to the fact that most parents no longer play the supportive and complementary role of congruent assistance to the students in the career decision making. Rather they insist on a particular career for the students based on their age, educational qualifications, gender and religion. This account for the many cases of dropout of undergraduate students who have reluctantly left their career aspirations due to pressure from their parents. As a result, the students' go in to study courses to please their parents even when they do not have the necessary skills or abilities to excel in them.

However, there are also students who vehemently resist this attempt by their parents to deny them of their freedom to make appropriate career decisions or choice. Hence, they reject the career chosen by their parents on the ground that such decisions are not to their best interest. But these are just a minority compared to the enormous number of students who drop out of school because their career aspirations have been disfigured or marred by their parents' choice for them.

Previous researchers have done a lot of work on career choice. Alika (2010) conducted a study on parental and peer group influence as correlates to career choice in humanities. The findings showed that parents and peer group tend to influence an individual career choice more than any factor. 


\section{Famolu}

Researchers like Miller, Dilorio and Dudley (2012) carried out a study on relationship between parenting styles and adolescent's reaction to conflict. The findings of the study showed that family is a place, in which skills are taught and the groundwork for enhancement of personality and increasing of adaptability is laid. The researchers believe that in order to control the emotions and limit behaviours, the personality should be adequately disciplined. Instability of personality is mostly observed in those adolescents who have permissive mothers. Lazarus, Mohammed and Adigun (2012), examined parenting styles and self-concept on educational adjustment of Nigeria secondary school students. The findings revealed that parenting styles and self-concept have greater influence on emotional adjustments of the respondents. Adegboyega et al. (2017) conducted a study on the influence of parenting styles on social adjustment and academic achievement of adolescent students in selected secondary schools in Ogun Waterside Local Government of Ogun State.

To the best of the researcher's knowledge, none of these studies have focused on parenting styles as a determinant of career choice among undergraduates with disabilities at the University of Ilorin.

\section{Research Question}

This research question was raised to guide the conduct of the study:

1. Does parenting styles determine the career choice of undergraduates with disabilities at the University of Ilorin?

\section{Research Hypotheses}

The following hypotheses were postulated in a null form:

1. There is no significant difference in parenting styles as a determinant of career choice among undergraduates with disabilities at the University of Ilorin on the basis of gender.

2. There is no significant difference in parenting styles as a determinant of career choice among undergraduates with disabilities at the University of Ilorin on the basis of religion.

3. There is no significant difference in parenting styles as a determinant of career choice among undergraduates with disabilities at the University of Ilorin on the basis of age.

4. There is no significant difference in parenting styles as a determinant of career choice among undergraduates with disabilities at the University of Ilorin on the basis of level. 
Famolu

\section{Methods}

\section{Research Design}

The research design adopted for the study is a descriptive survey. A descriptive survey is one of the most reliable methods of carrying out research when dealing with a large population of respondents because it allows the researcher to use information collected from the sample respondents to generalize on the population. Clair (2011) stated that, a descriptive research is designed to portray accurately the characteristics of a particular individual, situation or group.

The descriptive survey method is considered appropriate for this study because, according to Olawuyi (2016), descriptive survey research has the advantage of being an effective method of gathering data from a large number or sources. The researcher adopted descriptive survey of the correlation type method because the study intends to investigate the parenting styles as a determinant of career choice among undergraduates at the University of Ilorin.

A descriptive survey allows the researcher to obtain the opinion of the representative samples of the targeted population in order to be able to infer the perception of the entire population, though it is non-experimental, for it deals with the relationship with the nonmanipulated variables in a natural rather than artificial setting. Descriptive survey research also has the advantage of being an effective way of collecting data from a large number of sources.

\section{Population, Sample and Sampling Procedure}

The population is a study group of interest to the researcher in which the research was generated. The population for this study consists of students with disabilities at the University of Ilorin while the target population was made up of students from various faculties at the University of Ilorin.

The sample comprises two hundred (200) undergraduates with disabilities at the University of Ilorin in Ilorin, Kwara State. These respondents were randomly selected using purposive and simple random sampling techniques.

\section{Instrumentation}

Instrumentation is a vital aspect in research. It refers to the tools or means by which researchers attempt to measure variables or items of interest in the data collection process (Salkind, 2010). The instrument used for the study to collect data from the participants was a researcher-designed questionnaire titled "Parenting Styles as Determinant of Career Choice Questionnaire (PSDCCQ)". The questionnaire was divided into two (2) different sections: 'A', and ' $B$ '. Section ' $A$ ' contained the demographic information of the respondents including gender, religion, age range and level. Section 'B' contains 20 items on parenting styles as determinants of career choice among Undergraduates' with disability in University of Ilorin. The instrument was patterned after the four-point Likert-type Rating Scale format of: 
Famolu

$\begin{array}{lll}\text { Strongly Agree } & (\mathrm{SA})= & 4 \text { points } \\ \text { Agree } & (\mathrm{A})= & 3 \text { points } \\ \text { Disagree } & \text { (D) }= & 2 \text { points } \\ \text { Strongly Disagree } & \text { (SD) }= & 1 \text { point }\end{array}$

The participants responded to the items by ticking the option they think was more appropriate to the statement based on their feelings or opinions.

\section{Validity}

The validity of an instrument is the ability of that instrument to assess what it was designed to assess (Kendra, 2010). The validity of instrument refers to how well the instrument measures what it sets out to measure; that is how true or accurate an instrument is (Adegboyega, 2018). Content validity is one of the processes through which the validity of an instrument can be measured. It represents the degree to which the sample of the test items represents the content that the test is designed to measure. In order to establish the content validity of the instrument, the questionnaire, after being drawn by the researcher, was given to five (5) experts in counselling for vetting. The corrections and comments that were made by these experts were strictly adhered to.

\section{Reliability}

A reliable instrument is one that if administered a second time gives the same result as it did the first time (Adegboyega, 2018). Reliability of the instrument was ascertained using test retest method. This was done by administering the test to undergraduates within an interval of two weeks. The two set of scores were correlated using Pearson Product Moment Correlation formula (PPMC). A co-efficient of 0.86 was obtained, hence, the instrument was adjudged reliable for the study.

\section{Procedure for Scoring}

Scoring as it connotes implies the scaling and rating adopted for the instrument. A four-point likert-type was set against each items as follows; strongly agree=4points, agree=3points, disagree $=2$ points, strongly disagree $=1$ point. Thus, the highest score is four while the lowest score is one. Section B which comprises of twenty questions each, the highest score any respondent can get is 80 (i.e. 4 x 20) while the lowest possible score respondent can get is 20 (i.e. 
$1 \times 20$ ) the total number is 20 items which means the total highest score will be 80 while the total number of the lowest score will be 20. Therefore, the range is 60 (80-20).

\section{Data Analysis}

Data collected were analysed using descriptive and inferential statistical measures. The hypotheses were tested using t-test and Analysis of Variance (ANOVA) statistical procedures. All hypotheses were tested at 0.05 level of significance. Cull (2011) considered t-test as a parametric test often used by researchers to compare the mean of two groups while ANOVA is an inferential statistic for comparing the means of three or more groups.

\section{Results}

The data presented in Table 1 to 4 included demographic characteristics of the respondents' and percentages. The moderating variables used were gender, religion, age and level.

Table 1: Percentage Distribution of the Respondents based on Gender

\begin{tabular}{ccc}
\hline Gender & Frequency & Percentage (\%) \\
Male & 79 & 39.5 \\
Female & 121 & 60.5 \\
Total & $\mathbf{2 0 0}$ & $\mathbf{1 0 0}$ \\
\hline
\end{tabular}

Table 1 reveals that 79(47.5\%) respondents were male while 121(60.5\%) respondents were female. This shows that more males participated than females in the study. 
Table 2: Percentage Distribution of the Respondents on Religion

\begin{tabular}{ccc}
\hline Religion & Frequency & Percentage (\%) \\
\hline ATR & 8 & 4.0 \\
Christianity & 72 & 36.0 \\
Islam & 120 & 60.0 \\
Total & $\mathbf{2 0 0}$ & $\mathbf{1 0 0}$ \\
\hline
\end{tabular}

Table 2 reveals that $8(4.0 \%)$ respondents were traditional religion adherent, $72(36.0 \%)$ respondents were practicing Christianity, while $120(60.0 \%)$ respondents were practicing Muslims.

Table 3: Percentage Distribution of the Respondents Based on Age

\begin{tabular}{ccc}
\hline Age & Frequency & Percentage $(\%)$ \\
\hline 15-19 years & 61 & 30.5 \\
20-24 years & 120 & 60.0 \\
25years \& above & 19 & 9.5 \\
Total & $\mathbf{2 0 0}$ & $\mathbf{1 0 0}$ \\
\hline
\end{tabular}

Table 3 reveals that $61(30.5 \%)$ respondents were in between $15-19$ years of age, $120(60.0 \%)$ respondents were between 20-24 years of age, while, 19 (9.5\%) of the respondents were 25 years and above. 
Table 4: Percentage Distribution of the Respondents Based on Level

\begin{tabular}{ccc}
\hline Level & Frequency & Percentage (\%) \\
100 & 32 & 16.0 \\
200 & 69 & 34.5 \\
300 & 36 & 18.0 \\
400 & 49 & 24.5 \\
500 & 14 & 7.0 \\
Total & 200 & 100 \\
\hline
\end{tabular}

Table 4 reveals that $32(16.0 \%)$ respondents were 100 level students, $69(34.5 \%)$ of the respondents were 200 level students, 36 (18.0\%) respondents were 300 level students, 49 $(24.5 \%)$ of the respondents were 400 level students, while 14 (7.0\%) of the respondents were 500 level students.

Research Question: What are the influences of parenting styles as a determinant of career choice?

Table 5: Mean and Rank Order Analysis on Influence of Parenting Styles as a Determinant of Career Choice

\begin{tabular}{|c|c|c|}
\hline $\begin{array}{l}\text { Item } \\
\text { No }\end{array}$ & As far as I am concerned, my parents: & Mean \\
\hline
\end{tabular}

9. Discuss the problem that may encountered during the choosing $3.63 \quad 1^{\text {st }}$ my choice of career.

4. Give directives in all my choice of career $\quad 3.61 \quad 2^{\text {nd }}$

14. Explains most things to me regarding my choice of career $3.58 \quad 3^{\text {rd }}$ without directives from them

10. Set clear rules for me to choose my choice of career. $3.55 \quad 4^{\text {th }}$

20. Do not care if there are rules or conduct choosing my choice $3.53 \quad 5^{\text {th }}$ of career.

5. Severe punishment is imposed on me during my choice of $3.50 \quad 6^{\text {th }}$ career 
16. Care much about my choice of choosing career

15. Discuss my opinion and emotions on my choice of career with me

1. Authoritatively ask about my choice of career in school from

$9^{\text {th }}$ my level adviser

17. Do not encourage me to choose the best career for myself.

11. Permit me to choose the choice of career without any restriction

6. Impose the choice of career on me without any hesitation

2. Established high degree of interaction on my choice of career with my level adviser

13. Care less about my choice of career

18. Is always supportive on my choice of career choosing

7. Encourage me to choose career that will make them happy

12. Does not monitor my choice of career

8. Do not guide on me choice of career

3. Put much pressure on me on the choice of career in school

Table 5 shows the mean and the rank on the influence of parenting styles as a determinant of career choice. Item 9 which stated that "Discuss the problem that may encountered during the choosing my choice of career" with mean score of 3.63 ranked $1^{\text {st }}$, item 4 which stated that "Give directives in all my choice of career" with mean score of 3.51 ranked $2^{\text {nd }}$ while, item 14 which stated that "Explains most things to me regarding my choice of career without directives from them" ranked $3^{\text {rd }}$ with a mean score of 3.48. Similarly, item 8 which stated that "Do not guide on me choice of career" ranked $18^{\text {th }}$ with a mean score of 3.14 , Item 3 which stated that "Put much pressure on me on the choice of career in school" ranked $19^{\text {th }}$ with mean score of 3.10 while, item 19 which stated that "Never had time to check on my choice of career" ranked $20^{\text {th }}$ with a mean score of 3.05. It was revealed that all the statements have a mean score above the midpoint of 2.50, therefore, it can be concluded that all the items on this section posited the influence of influence of parenting styles as a determinant of career choice. 


\section{Famolu}

\section{Hypotheses Testing}

Four null hypotheses were formulated and tested for this study. The hypotheses were tested using t-test and ANOVA statistical methods at a 0.05 level of significance. The results are presented as follows:

Hypothesis One: There is no significant difference in the influence of parenting styles as a determinant of career choice based on gender.

Table 6: Mean, Standard Deviation and t-value on the Influence of Parenting Styles as a Determinant of Career Choice Based on Gender

\begin{tabular}{lccccccc}
\hline Gender & N & Mean & SD & Df & Cal. t-value & Crit.t-value & p-value \\
\hline Male & 79 & 54.9114 & 3.63 & 198 & .03 & 1.96 & .98 \\
Female & 121 & 54.9256 & 3.21 & & & & \\
\hline
\end{tabular}

Table 6 shows a calculated t-value of .03 , a critical t-value of 1.96 , and a p-value of .98 . The critical t-value of 1.96 is greater than the calculated t-value of .03 at 0.05 level of significance. Hence, the hypothesis is not rejected. This implies that there is no significant difference in the influence of parenting styles as determinant of career choice based on gender.

Hypothesis Two: There is no significant difference in the influence of parenting styles as a determinant of career choice based on based on religion.

Table 7: ANOVA Result Showing Difference on the Influence of Parenting Styles as a Determinant of Career Choices Based on Religion

\begin{tabular}{lrrrccc}
\hline \multicolumn{1}{c}{ Age } & \multicolumn{1}{c}{ SS } & df & MS & Cal. F-ratio & Crit. F-ratio & P-value \\
\hline Between group & 49.753 & 2 & 24.877 & 2.21 & 3.00 & .113 \\
Within group & 2220.967 & 197 & 11.274 & & \\
Total & 2270.720 & 199 & & & \\
\hline
\end{tabular}




\section{Famolu}

Table 7 indicates a calculated F-ratio of 2.21, a critical F-ratio of 3.00, and a p-value of .113 at 0.05 alpha level of significance. Since the calculated F-ratio of 2.20 is less than the critical Fratio of 3.00 hence, the hypothesis is not rejected. There is no significant difference in the influence of parenting styles as determinant of career choices based on religion.

Hypothesis Three: There is no significant difference in the influence of parenting styles as a determinant of career choice based on based on age.

Table 8: ANOVA Result Showing Difference on the Influence of Parenting Styles as a Determinant of Career Choices Based on Age

\begin{tabular}{lrrrrrr}
\hline $\begin{array}{l}\text { Number of } \\
\text { Siblings }\end{array}$ & \multicolumn{1}{c}{ SS } & \multicolumn{1}{c}{ df } & MS & Cal. F-ratio & Crit. F-ratio & P-value \\
\hline Between group & 84.568 & 2 & 42.284 & $3.810^{*}$ & 3.00 & .024 \\
Within group & 2186.152 & 197 & 11.097 & & & \\
Total & 2270.720 & 199 & & & & \\
$* \mathrm{P}<0.05$ & & & & & &
\end{tabular}

Table 8 indicates a calculated F-ratio of 3.810, a critical F-ratio of 3.00, and a p-value of .024 at 0.05 alpha level of significance. Since the calculated F-ratio of 3.810 is greater than the critical Fratio of 3.00 hence, the hypothesis is rejected. There is a significant difference in the influence of parenting styles as determinant of career choices based on age.

Table 9: DMRT on the Influence of Parenting Styles as a Determinant of Career Choices Based on Age

\begin{tabular}{ccccl}
\hline $\begin{array}{l}\text { Duncan } \\
\text { Groupings }\end{array}$ & N & Means & Group & Age \\
\hline A & 120 & 54.3917 & 1 & $20-24$ years \\
A & 61 & 55.6557 & 1 & $15-19$ years \\
A & 19 & 55.8947 & 1 & 25 years \& above \\
\hline
\end{tabular}


Table 9 shows the significant differences in the age of respondents. The table indicates that the difference occurs within the group (i.e. group 1), the mean differences are 54.3917, 55.6557, 55.8947. This shows that the difference occurs within the group.

Hypothesis Four: There is no significant difference in the influence of parenting styles as a determinant of career choice based on based on level.

Table 10: ANOVA Result Showing Difference on the Influence of Parenting Styles as a Determinant of Career Choices Based on Level

\begin{tabular}{lrccccc}
\hline Source & SS & df & MS & Cal. F-ratio & Crit. F-ratio & P-value \\
\hline Between group & 84.568 & 2 & 42.284 & $3.80 *$ & 3.00 & .024 \\
Within group & 2186.152 & 197 & 11.097 & & & \\
Total & 2270.720 & 199 & & & \\
\hline
\end{tabular}

$* \mathrm{P}<0.05$

Table 10 indicates the calculated F-ratio of 3.80, critical F-ratio of 3.00, and a p-value of .024 at 0.05 alpha level of significance. Since the calculated F-ratio of 3.80 is greater than the critical Fratio of 3.00 hence, the hypothesis is rejected. There is a significant difference in the influence of parenting styles as determinant of career choices based on level.

Table 11: DMRT on the Influence of Parenting Styles as a Determinant of Career Choices Based on Educational Level

\begin{tabular}{ccccl}
\hline $\begin{array}{l}\text { Duncan } \\
\text { Groupings }\end{array}$ & N & Means & Group & Level \\
\hline A & 32 & 68.30 & 1 & 100 level \\
B & 69 & 70.64 & 2 & 200 level \\
C & 36 & 71.37 & 3 & 300 level \\
D & 49 & 73.71 & 4 & 400 level \\
E & 14 & 67.90 & 5 & 500 level \\
\hline
\end{tabular}


Table 11 shows the significant differences in the educational level of which group A with a mean score of 68.30 differs from group B with a mean score of 70.64 significantly differs from group $\mathrm{C}$ with a mean score of 71.37 significantly differs from group D with a mean score of 73.71 and significantly differs from group $\mathrm{E}$ with a mean score of 67.90 . The difference shown in the table constitute to the differences noted in the ANOVA noticed in Table 10.

\section{Discussion}

The study revealed that the influence of parenting styles as a determinant of career choice includes: discuss the problem that may encountered during the choosing my choice of career. This implies that the parents discuss what their child might encounter when choosing their choice of career. This corroborates with the findings of Larzelere, Morris \& Harrist (2013) who expressed that authoritative parents provide guidance to their children on issue oriented and rational matters and the level of demand is high, along with effective communication which builds an effective relationship between the child and the parents.

It was also revealed that giving directives in all my choice of career, explains most things to me regarding my choice of career without directives from them. This implies that the parent guides their children and explains most things regarding their choice of career. This corroborates with the findings of Lao (2014) who expressed that authoritarian parents believe it is their responsibility to provide for their children and that their children have no right to tell the parent how best to do this.

It was also revealed that respondent's parents permit them to choose their choice of career without any restriction. This implies that the respondents are permitted to choose their choice of career without any restriction. This corroborates with the findings of Aunola (2000) who expressed that the permissive parent is typically child-centred, providing a large amount of communication and positive feedback and encouraging development of self-enhancing attributes.

It was also revealed that the respondent's parents encourage them to choose a career that will make them happy amongst others. This implies that the respondents are encouraged to choose the choice of career that will make them happy. This corroborates with the findings of Joseph (2014) who expressed that they feel their child are capable of making their own decisions with little parental guide. In effect, these parents are extremely supportive, to the extent that they wind up taking control of the situation.

Another finding revealed that there was no significant difference in the influence of parenting styles as a determinant of career choice based on gender This does not corroborate with the findings of Dauda (2011) who found that authoritarian parents show significant differences in how they help their sons and daughters in a choice of career and thus, they demonstrate more interest, and provide more encouragement and challenges to their sons compared o their daughters. This implies that an authoritarian parent do not allow or discriminate their female child from choosing a career designated to be for men only. 
Findings also revealed that there was no significant difference in the influence of parenting styles as a determinant of career choice based on religion. This corroborate with the findings of Arbogest (2018) who expressed that regardless of the parenting style, individual parent who are religiously extrinsically-oriented, either personal extrinsic or social extrinsic will exhibit higher level of care in making career decisions for their children.

Findings also revealed that there was a significant difference in the influence of parenting styles as determinant of career choices based on age. This corroborates with Berk (2013) who stated that young adolescents with parents who use an authoritarian pattern are low in acceptance and are involved less in career decisions of their children and that an adolescent with authoritarian parents is less adjusted in career choices than those from authoritative parents. Similarly, Melgosa (2016) as cited in Abbas (2015), revealed that the younger an adolescent with authoritarian parents is, the more they suffer from a poor self-concept when faced with career decisions.

Findings revealed that there was a significant difference in parenting styles as a determinant of career choices based on educational level. The result shows that the hypothesis was rejected. This is in line with Nduka (2019) who opined that children of democratic parents who are highly educated are the best adjusted, they develop a positive self-concept and are more successful in making career decisions in life. Abbas (2015) who also viewed how learned democratic parents set limits and enforce rules, and listen to their children's requests, questions, discussions, feelings and yet, they do not tend to influence their children's career decisions.

\section{Conclusion}

Based on the findings of this study, the following conclusions were drawn:

The influence of parenting styles as determinant of career choices include: discuss the problem that may encountered during the choosing my choice of career, give directives in all my choice of career, explains most things to me regarding my choice of career without directives from them, permit me to choose the choice of career without any restriction, encourage me to choose a career that will make them happy, many amongst others. There was no significant difference in the influence of parenting styles as a determinant of career choices based on gender. There was no significant difference in the influence of parenting styles as a determinant of career choices based on religion. There was no significant difference in of parenting styles as a determinant of career choices based on age. There was no significant difference in the influence of parenting styles as a determinant of career choices based on level.

\section{Recommendations}

Based on the findings of this study, the following recommendations were made: 
1. Professional school counsellors should provide collaborative support and training to parents on career guidance. This is because their education, skills, and position within the school community place them in a unique position to assess the needs of adolescents, and the skills and stressors of their parents.

2. School counsellors should assist parents in providing career-related modelling for their adolescents by showing them how to talk to their adolescents about their own occupations as well as about other occupations that are available in the world of work.

3. Parents should imbibe the development of basic work attitudes as promptness, respect, dedication, expression of positive regard to constituted authority, and responsibility. This is necessary considering the fact that their attitude to work will have a significant effect on their children's career choice.

4. School counsellors in alliance with parents should provide opportunities that would nurture interests in vocational subject matter, and create environments that would nurture the discovery of aptitudes for vocational content.

5. Parents should respect their children's differences. Family environments that show respect for differences and independence would be enormously helpful to the child's career development.

6. School counsellors can assist parents in learning how to provide emotional support by helping them understand the emotions that adolescents experience when faced with difficult educational and vocational challenges, by helping parents talk to their adolescents about what fun their future job could be. 


\section{References}

Adegboyega, L. O. (2017). Environmental influence on career choice of undergraduates at University of Ilorin: Implications for counselling. KIU Journal of Social Sciences, 3(2), 59-70.

Adegboyega, L. O., Ibitoye, O. A., Okesina, F. A. \& Lawal, B. M. (2017). Influence of parenting styles on social adjustment and academic achievement of adolescent students in selected secondary schools in Ogun waterside local government of Ogun State. Anatolian Journal of Education, 2(1), 11-20.

Adegboyega, L. O. (2018). Influence of achievement motivation on Nigerian undergraduates' attitude towards examination. International Journal of Instruction, 11(1), 77-88.

Adegboyega, L. O. (2019). Single parenting and emotional development of primary school students as viewed by Nigerian primary school teachers. Mimbar Sekolah Dasar, 6(1), 116-125.

Alegre, A. (2018). Parenting styles and children's emotional intelligence: What do we know? The Family Journal, 19, 56. doi: 10. 1177/1066480710387486.

Alika, I.H. (2010). Parental and peer group influence as correlates of career choice in humanities among secondary school students in Edo State, Nigeria. Journal of Research in Education and Society, 1(1), 1-8.

Aunola, K. (2010). Parenting styles and adolescents' achievement strategies. Journal of Adolescence, 23, 205-222.

Baumrind, D. (2011). Effective parenting during the early adolescent transition. In P. A. Cowan \& E.M. Hetherington (Eds.) Family transitions. Advances in family research series. Hillsdale, New Jersey, England: Lawrence Erlbaum Associates, Incorporation.

Baumrind, D. (2011). The influence of parenting style on adolescent competence and substance use. Journal of Early Adolescence, 11, 56-95.

Baumrind, D. (2011). Parenting styles and adolescent development. In Brooks Gunn, J. (ed). The encyclopedia of adolescence, New York, Garland publishing Incorporation.

Clair, R. (2011). Research design. Retrieved from https://www.linkedin.com

Dustman, C. (2014). Parental background, secondary school track choice and wages. Oxford Economic Papers, 56; 209-213.

Egbochuku, E.O. (2019). Vocational Interest, Counselling, Socio-economic Status and Age as Correlates of the Re-entry of Girls into School. Edo Journal of Counselling, 2 (1) 9-15.

Gay, L.R. (2015). Educational research competencies for analysis and application. Merril Publishing Co., Columbus. Retrieved June 13, 2017 from https://www.stat.purdue.edu

Gwen, D. (2010). Parenting styles: A guide for the science-minded. Retrieved from http://www.parentingscience.com, Accessed on 15 th January, 2019.

Joseph, L. E. (2014). Permissive parenting style. In Goldstein.S, \& Nagliere. A. J.,(Eds), Encyclopedia of Child Behavior and Development (pp. 1080-1090). New York: Springer.

Kendra, C. (2010). Research in psychology. Retrieved from http://www.about.com/research_in_psychology.html.

Larzelere, A. S. Morris, B. \& Harrist, A. W. (2013). Authoritative parenting: Synthesizing nurturance and discipline for optimal child development (pp. 61-88). Washington DC: American Psychological Association. 
Lee, H.-Y., \& Hughey, K. F. (2011). The relationship of psychological separation and parental attachment to the career maturity of college freshmen from intact families. Journal of Career Development, 27, 279-293.

Melgosa, S. (2016). Gender stereotyping of career choice cited fromhttp://www.careersscotland.org, Accessed on $15^{\text {th }}$ January, 2019.

Miller, J., Dilorio, C., \& Dudley, W. (2012). Parenting style and adolescent's reaction to conflict: is there a relationship? Journal of Adolescent Health, 31, 463-468.

Navin, D. S. (2019). Effects of dating and parental attachment on career exploration. USA, University of New Hampshire.

Nduka, O. A. (2019). Contemporary issues. New York, MCGraw-Hill Press.

Pilot, M. \& Regis, C (2012). Socio-demographic Factors Influencing Career Decision making among Undergraduate Psychology Students in South Africa. Journal of Social Science, 31(2), 167-176.

Salkind, N. J. (2010). Encyclopedia of research design. Thousand Oaks, Calif: SAGE Publications.

Spera, C. (2015). A review of the relationship among parenting practices, parenting styles and adolescent school achievement. Educational Psychology Review, 17 (2), 125-146.

Trusty, J. Watts, R.E. \& Erdman, P. (2017). Predictors of parents' involvement in their teens' career development. Journal of Career Development, 23, 189-201. 